\title{
Tvorba databáze pro oceňování pozemků
}

\section{Creating Database for Valuation of Land}

\author{
Pavel Klika ${ }^{a^{*}}$, Alena Klikováb \\ a Vysoké učeni technické v Brně, Ústav soudního inženýrství, Brno \\ ${ }^{b}$ Masarykova univerzita, Právnická fakulta, Brno
}

\begin{abstract}
Abstrakt
Př́íspěvek je zaměřen na problematiku možného vytvoření databáze pro stanovení tržní hodnoty pozemků cenovým porovnáním. V př́spěvku se autoři zaměřili na vybrané otázky související se stanovováním tržní hodnoty pozemků. Jsou vymezeny základní vlastnosti pozemků, na kterých závisí správná volba porovnatelného pozemku pro ocenění. Za vlastnosti pozemků, které tvoří základ pro zvolenou metodu oceňování tržní hodnoty pozemků, můžeme označit nejenom druh pozemku uvedený v katastru nemovitostí, ale i zařazení pozemku územním plánem pro jeho využití. Není opomenuta problematika otázek souvisejících s evidencí druhu pozemku v katastru nemovitostí, změny druhu pozemku, způsoby evidence těchto změn a otázky územního plánování. Podrobně je rozebrána problematika jednotkových cen srovnávaných pozemků, zejména odchylky ve výši jednotkové ceny realizovaných prodejů pozemku. $V$ př́spěvku je uveden príklad tvorby databáze pro vybrané druhy pozemku. Na príkladu jsou ukázány reálné problémy vznikající při stanovování tržních hodnot konkrétních pozemků porovnávacím způsobem.
\end{abstract}

Klíčová slova: katastr nemovitostí, databáze, oceňování, část pozemku, druh půdy.

\section{1. ÚVOD}

Předkládaný příspěvek je zaměřen primárně na problematiku možného vytvoření databáze pro stanovení tržní hodnoty pozemků cenovým porovnáním. Daná problematika je primárně řešena pravidly pro oceňování a je provázána s otázkami právními, a to konkrétně s evidencí v katastru nemovitostí, s vymezením druhu pozemku a s územním plánováním. Na úvod je nutno uvést, že pravidla pro určení druhu pozemku a požadavky na zařazení pozemku územním plánem pro jeho využití lze zařadit do tzv. veřejného práva, kdy existuje a uplatňuje se zájem státu (bez ohledu na státní zř́izení) na regulaci výstavby. Právě tato regulace výstavby,

\section{Abstract:}

The talk will be focused on the subject matter of possible creation of a database for determining market value of land using price comparison. The authors will focus upon selected questions regarding determining market value of land. They will define basic properties of land pieces, which are essential for the right choice of another comparable piece of land for valuation. The properties that are essential for selecting the method of valuation of market value of land are not only the kind of land stated in the land cadastre but also the classification of the land within the territorial plan due to its use. They will also talk about the subject matter linked with recording the kind of land within the land cadastre, changes in the kind of land, ways of recording the changes and questions regarding territorial planning. The authors will speak in detail about the subject matter of unit prices of the compared pieces of land, especially regarding the deviations in the sum of unit price in the implemented sales of land. The talk will include an example of creating a database for selected pieces of land. The example will serve for illustrating all the real problems arising when determining market value of concrete pieces of land using the comparison method.

Keywords: land cadaster, database, valuing, piece of land, kind of land.

resp. regulace možností využití pozemků nejenom pro výstavbu, či pro možnost umíst'ování konkrétních typů staveb, může mít vliv na určení hodnoty samotného pozemku. Autoři považují za vhodné vymezit základní možné formy databáze vybraných druhů pozemků pro stanovování tržních hodnot konkrétních pozemků porovnávacím způsobem. Srovnatelné pozemky pro stanovení databáze budou určeny v návaznosti na jejich vlastnosti, nebot' na nich závisí správná volba porovnatelného pozemku pro ocenění. Za vlastnosti pozemků, které tvoří základ pro zvolenou metodu oceňování tržní hodnoty pozemků, označujeme např. druh pozemku uvedený $\mathrm{v}$ katastru nemovitostí a zařazení pozemku územním plánem pro jeho využití. 


\section{KATASTR NEMOVITOSTÍ A EVIDENCE DRUHU POZEMKU V NÁVAZNOSTI NA OCEŇOVÁNÍ}

Katastr nemovitostí je veřejný seznam, který obsahuje soubor údajů o nemovitých věcech vymezených katastrálním zákonem. Je jedním z veřejných seznamů, které předvídá zákon č. 89/2012 Sb., občanský zákoník. Každý veřejnoprávní soupis věcí má své zásady vedení a katastr v tomto směru nečiní žádnou výjimku. Občanský zákoník ( $\$ 984$ odst. 1) upřednostňuje stav zapsaný v katastru před stavem tvrzeným. Toto pravidlo nazýváme principem materiální publicity. Princip materiální publicity vede $\mathrm{k}$ dobré víře $\mathrm{v}$ zápisy v katastru. Katastr je zdrojem informací, které slouží mimo jiné k oceňování nemovitostí. Při oceňování nemovitostí se vychází z údajů katastru. Pro účely oceňování se pozemek posuzuje podle stavu uvedeného v katastru nemovitostí [1]. Pokud nastane situace, že se při oceňování zjistí nesoulad mezi stavem uvedeným v katastru nemovitostí a skutečným stavem, vychází se při oceňování ze skutečného stavu.

\section{3. ČLENĚNÍ POZEMKŮ PRO ÚČELY OCEŇOVÁNÍ}

Pro účely oceňování se pozemky člení na stavební pozemky, zemědělské pozemky, lesní pozemky, pozemky evidované v katastru jako vodní plochy a jiné pozemky, které nejsou výše uvedeny ( 9 odst. 1 zákona o oceňování majetku). [2] Další členění pozemků pro účely ocenění v návaznosti na druh pozemku a jeho účel užití stanoví vyhláška č. 441/2013 Sb., k provedení zákona o oceňování majetku (oceňovací vyhláška).

Katastr nemovitostí [3] odlišuje nejenom druh pozemku, ale i způsob jeho využití. Přesné rozlišení lze nalézt v katastrální vyhlášce č. 357/2013 Sb., a to v prílohách č. 1 a 2. Druh pozemku charakterizuje konkrétní pozemek, k čemu je určen. Způsob využití pak charakterizuje, k čemu konkrétně je pozemek využíván, co je na něm zř́zeno či pěstováno.

\subsection{Stavební pozemky}

Stavební pozemky se pro účely oceňování člení dle $\S 9$ odst. 2 zákona o oceňování majetku [2] na:

- nezastavěné pozemky,

- zastavěné pozemky,

- plochy pozemků skutečně zastavěné stavbami bez ohledu na evidovaný stav v katastru.

Nezastavěné pozemky dále dělíme $\mathrm{v}$ návaznosti na evidenci katastru nemovitostí na tyto druhy pozemku:

- zastavěné plochy a nádvoří,

- pozemky, které byly vydaným územním rozhodnutím, regulačním plánem, veřejnoprávní smlouvou nahrazující územní rozhodnutí nebo územním souhlasem určeny k zastavění; pokud právní předpis nebo územní plán stanoví nejvyšší př́ipustnou plochu zastavěnosti pozemku, je pro účely oceňování považován za stavební pozemek pouze část odpovídající přípustnému limitu určenému k zastavění,

- zahrady nebo ostatní plochy v jednotném funkčním celku; jednotným funkčním celkem se rozumějí pozemky v druhu pozemku zahrady nebo ostatní plochy, které souvisle navazují na pozemek evidovaný v katastru v druhu pozemku zastavěná plocha a nádvoří se stavbou, se společným účelem jejich využití; v jednotném funkčním celku může být i více pozemků druhu pozemku zastavěná plocha a nádvoří,

- pozemky s právem stavby.

Zastavěné pozemky se $\mathrm{v}$ návaznosti na evidenci $\mathrm{v}$ katastru nemovitostí dělí na druhy:

- zastavěné plochy a nádvoří,

- ostatní plochy, které jsou již zastavěny,

Pro účely oceňování je stavební pozemek vymezen i negativně, tj. zákon uvádí, co se nepovažuje za stavební pozemek pro tyto účely. Stavebním pozemkem pro účely oceňování není pozemek, který je zastavěn jen podzemním nebo nadzemním vedením včetně jejich př́slušenství, podzemními stavbami, které nedosahují úrovně terénu, podzemními částmi a př́slušenstvím staveb pro dopravu a vodní hospodářství netvořícími součást pozemních staveb. Stavebním pozemkem pro účely oceňování není též pozemek zastavěný stavbami bez základů, studnami, ploty, opěrnými zdmi, pomníky, sochami apod.

\subsection{Zemědělské pozemky}

Za zemědělské pozemky označujeme pozemky určené k zemědělské výrobě. V katastru nemovitostí mohou pak být evidovány jako orná půda (pozemek obdělávaný za účelem produkce plodin nebo pozemek, který je k dispozici pro rostlinnou výrobu, ale je ponechán ladem, př́ípadně pozemek, který je dočasně zatravněn v rámci systému stř́dání plodin), chmelnice (pozemek, na kterém se pěstuje chmel a který je opatřen opěrným zařízením pro jeho pěstování, včetně plochy souvisejícího manipulačního prostoru, který netvoří součást cesty), vinice (pozemek rovnoměrně a souvisle osázený keři vinné révy opatřený opěrným zařízením, včetně plochy souvisejícího manipulačního prostoru, který netvoří součást cesty). Dále může být zemědělský pozemek evidován jako zahrada, ovocný sad a trvalý travní porost.

\subsection{Lesní pozemky}

Lesní pozemky, které můžeme členit na pozemky s lesním porostem a pozemky, u nichž byly lesní porosty odstraněny za účelem jejich obnovy, lesní průseky a nezpevněné lesní cesty, nejsou-li širší než $4 \mathrm{~m}$, a pozemky, na nichž byly lesní porosty dočasně odstraněny na základě rozhodnutí orgánu státní správy lesů.

\subsection{Vodní plochy}

Vodní plochy pro účely oceňování jsou pozemky evidované v katastru jako vodní plochy, tj. pozemky, na nichž je koryto vodního toku, vodní nádrž, močál, mokřad nebo bažina.

\section{ZMĚNY DRUHU POZEMKŮ}

České právní předpisy předpokládají pro zamýšlenou změnu účelu využití pozemků povolení ze strany orgánů veřejné správy, konkrétně stavebního úřadu. Stavební úřad územním rozhodnutím povoluje nejenom změnu využití území a stanovuje nový způsob užívání pozemku, ale určuje taktéž podmínky jeho využití [4].

Rozhodnutí o změně využití území vyžadují:

- terénní úpravy, 
- stanovení dobývacího prostoru,

- odstavné, manipulační, prodejní, skladové nebo výstavní plochy,

- veřejná a neveřejná pohřebiště,

- změny druhu pozemku nebo způsobu využití pozemků, zejména zřizování, rušení a úpravy vinic, chmelnic, lesů, parků, zahrad a sadů, pokud podmínky nejsou stanoveny schválenými pozemkovými úpravami nebo jiným územním rozhodnutím,

- úpravy pozemků, které mají vliv na schopnost vsakování vody.

Tyto změny se vždy musí promítnout do katastru nemovitostí jako základní evidence nemovitostí, ze které se v rámci oceňování čerpají stěžejní informace.

\section{5. ÚZEMNÍ PLÁNOVÁNÍ A VYMEZENÍ POZEMKŮ}

Územní plánování představuje souhrn opatření, směřujících k vytváření předpokladů pro udržitelný rozvoj území, s ohledem na možnosti a meze nakládání s územím a jeho účelného využívání. Územní plánování směřuje k cílené regulaci nakládání a využivání konkrétního územní. Územní plány stanovují závazné regulativy pro prostorové a funkční uspořádání území. Vymezují plochy stavební a nestavební. V rámci tohoto vymezení jsou pak jednotlivé pozemky zařazovány do určených ploch s konkrétním účelem využití [5].

Regulační podmínky pro plochy stavební vymezují urbanistickou funkci (účel využití plochy). Účel využití je většinou vymezován pro plochy bydlení, plochy smíšené, plochy pracovních aktivit, plochy pro rekreaci, plochy pro veřejnou vybavenost, plochy pro dopravu, plochy pro technickou vybavenost.

Regulační podmínky pro plochy nestavební vymezují účel využití plochy většinou takto: plochy krajinné zeleně, plochy městské zeleně, plochy s objekty pro individuální rekreaci, vodní plochy, zemědělské plochy, pozemky určené k plnění funkce lesa, aj.

\section{TVORBA DATABÁZE PRO OCENĚNÍ POZEMKŮ}

Všechny oceňovací standardy mezinárodní [6] i národní, a i často zákony [2] či vyhlášky vztahujících se k oceňování majetku, jako nejvhodnější způsob pro odhad tržní hodnoty uvádějí porovnání majetku a jeho cen. Pro to, abychom mohli provádět cenové porovnání, je nutné vytvoření kvalitní databáze porovnatelných objektů. U některého typu majetku, se kterým se běžně obchoduje, a ceny respektive trh nejsou nijak deformovány, lze tuto databázi vytvořit relativně jednoduše. Může se jednat naprríklad o běžný automobil, u kterého lze velmi často najít do databáze téměř shodné prvky v dostatečném množství. U pozemků je tvorba databáze mnohem složitější. Jedním ze základních cenotvorných parametrů pro cenu pozemku je jeho poloha, která je vždy jedinečná. Pro tvorbu databáze je pak zásadní, aby porovnávané pozemky byly v lokalitě stejné nebo alespoň co nejpodobnější. Tím se nám množství vhodných pozemků pro porovnání výrazně snižuje. Dalším zásadním kritériem je možnost využití pozemku. Je zcela zřejmé, že orná půda bude mít zcela jinou hodnotu než pozemky pro výstavbu. Jak již bylo uvedeno v předchozích odstavcích a $v$ rámci př́spěvku „Determination of the influence of conditions for the buildings placement on the value of the land using HABU method", na konferenci $17^{\text {th }}$ International Multidisciplinary Scientific Geoconference SGEM 2017, je hodnota pozemku jeho možným využitím ovlivněna zcela zásadně. Při tvorbě databáze tedy musíme tyto dvě zásadní vlastnosti pozemku vyhodnocovat jako prioritní a zařazovat prvky databáze, pokud je to možné, zásadně ve stejné nebo srovnatelné lokalitě a s předpokládaným shodným využitím pozemku.

Problematika tvorby databáze byla prozatím autory zkoumána pouze v České republice. Autoři předpokládají, že problematika bude shodná i v okolních zemích, což bude řešeno v následujícím výzkumu. Při zkoumání byly vytvořeny rozsáhlé databáze realizovaných kupních cen. Nejrozsáhlejší databáze, na které si ukážeme v tomto článku zásadní problémy, byla vytvořena z realizovaných kupních cen pozemků v hlavním městě ČR Praze. Jedná se o databázi 4200 realizovaných prodejů pozemků během let 2012 až 2016. Jednalo se o pozemky různého typu, různých velikostí a s různým využitím. U všech typů pozemků a ve všech časových obdobích se však projevovaly stejné nesrovnalosti. Autoři tohoto článku chtějí na tyto vlastnosti v následujících odstavcích upozornit, aby se čtenář vyvaroval chyb při tvorbě databází pro ocenění pozemků porovnáním.

\subsection{Výběr prvků z databáze do porovnání}

Pro ukázku autoři vybrali výběr prvků pro porovnání z prodejů pozemků v roce 2014 , pozemky dle katastru nemovitostí v druhu orná půda, zařazených v územním plánu Hlavního města Prahy v plochách pro čisté bydlení (výstavba rodinných a bytových domů) v okrajových částech města (tab. 1). Tímto omezením jsme získali z celé rozsáhlé databáze o 4200 prvcích databázi pouze se 17 prvky. Z toho je zřejmé, že získání vhodných porovnatelných prvků je velmi obtížné. Vzhledem k nutnosti utajení některých údajů nejsou ve článku uváděna konkrétní čísla parcel.

\subsection{Zjevné nesrovnalosti v databázi a nutné další odstranění prvků}

Pokud důkladně prozkoumáme vybrané prvky v databázi, jsou na první pohled viditelné 4 realizované prodeje za zcela shodnou cenu 7177 Kč. Toto nemůže být náhoda a při bližším průzkumu byl potvrzen předpoklad, že se jednalo o jednu transakci s více účastníky. Takovéto prodeje nelze uvažovat jako několik samostatných prvků do databáze, ale je nutné je uvažovat jako jeden prvek. Tímto postupem jsme snížili počet prvků v databázi o další tři na 14.

Dalším zásadním problémem je velká odchylka mezi maximem a minimem jednotkové ceny pozemku. Minimální hodnota je $2011 \mathrm{Kč} / \mathrm{m}^{2}$ a maximální hodnota je $22469 \mathrm{Kč} / \mathrm{m}^{2}$. Maximální hodnota je tedy více jak desetinásobná oproti hodnotě minimální. Těmto maximálním a minimálním hodnotám je třeba se při tvorbě databáze opět vyhnout. Je však velmi obtížné vyhodnotit, která z hodnot je do databáze již vhodná a která nikoliv. Je např́klad v naší databázi vhodná hodnota $3594 \mathrm{Kč} / \mathrm{m}^{2}$ či nikoli? Při podrobném zkoumání těchto prodejů v rámci výzkumu byly zjištěny dva faktory, které ceny v kupních smlouvách tímto extrémním způsobem ovlivňují. Nejedná se však o běžné cenotvorné faktory ale o jakousi deformaci trhu. Jedním z faktorů je spekulace 
Tab. 1 Databáze realizovaných prodejů pozemki̊ v druhu orná půda určených územním plánem k zastavění rodinnými domy. Tab. 1 Database of the undertaken sales in the form of arable land determined by the land use plan for the construction of family houses.

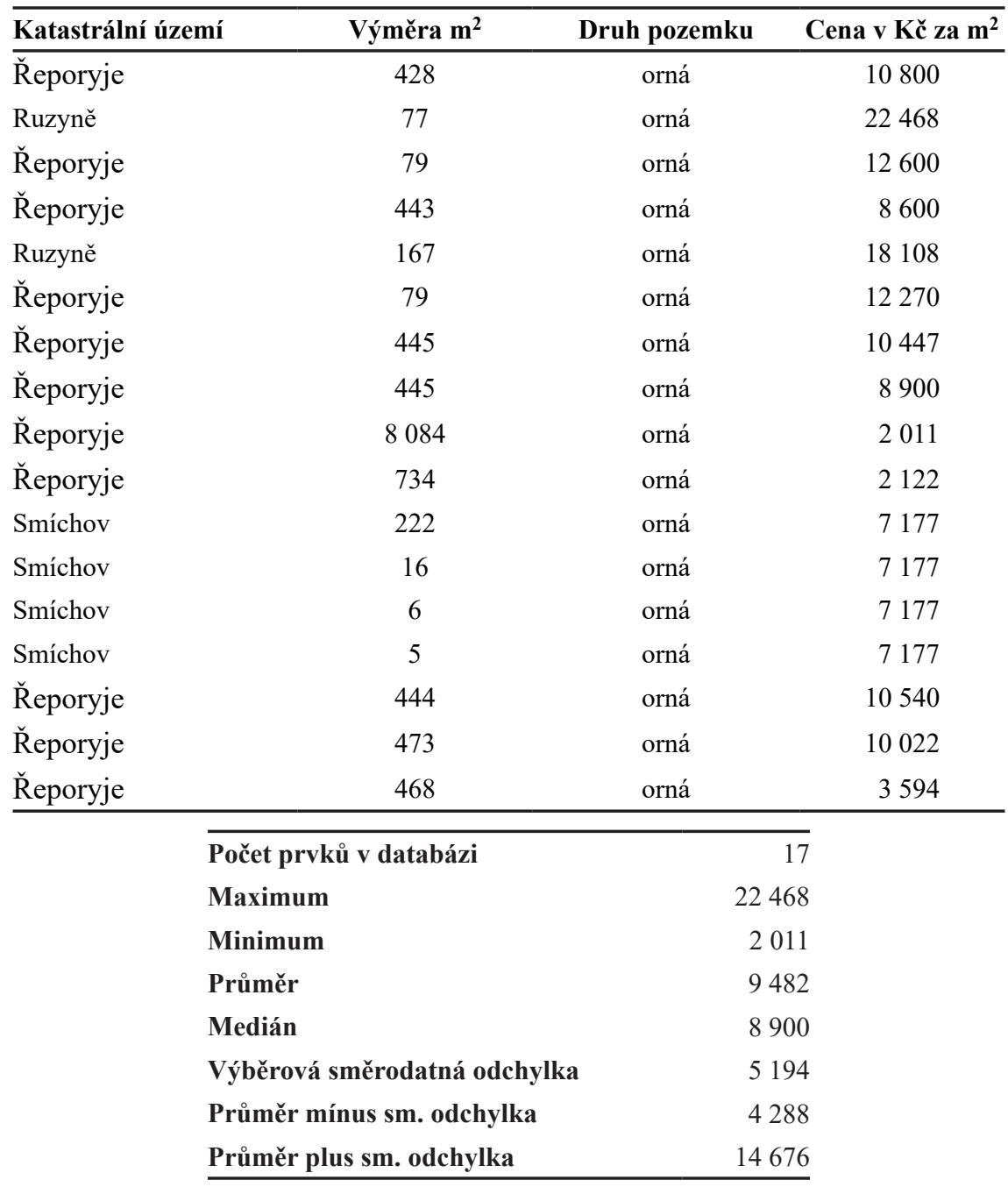

prodávajícího, respektive kupujícího a umělé navyšování ceny. Nejčastěji toto navyšování vzniká v př́ípadech, kdy developer pro svůj zájem potřebuje vykoupit pozemek, bez kterého by nebyl jeho projekt realizovatelný. V takovém př́ípadě je ochoten hodnotu pozemku přeplatit několikanásobně. Další zásadní deformace trhu vzniká při snaze snížit co možná nejvíce daňové zatížení například při koupi a následném prodeji např́klad z důvodu, že v ČR v určitých situacích není povinnost platit daň z převodu nemovitostí ze stavby ale z pozemku ano. Potom je zcela zjevně výhodnější cenu pozemku snížit na minimum a o sníženou cenu pozemku navýšit cenu stavby. Při průzkumu jsme se setkali s př́ípadem, kdy $\mathrm{v}$ jedné prodejní transakci byly prodány dva zcela shodné sousední pozemky, a jednotková cena jednoho pozemku byla desetinásobná oproti pozemku druhému. Při průzkumu bylo zjištěno, že tyto extrémní odchylky se nevyskytují u nabídkových cen v realitní inzerci. Autoři tedy doporučují nevycházet pouze z databází realizovaných prodejů ale ověřit si ceny i na základě inzerce. Při nabídce je zpravidla cena vyšší než konečná realizovaná, v nabídce však není důvod uvádět cenu, která bude ovlivněna spekulací či pokusem snížit daňové zatížení, a tedy navýšení nebude vykazovat extrémní hodnoty. Pro vyloučení extrémních hodnot lze u databází využít i Grubbsova parametrického testu nebo Dean Dixonova neparametrického testu. Tyto testy vyloučí extrémní hodnoty, neodhalí však spekulativní jednání účastníků směnného obchodu. Na vyloučení extrémů byl při stanovení prvků databáze použit Grubbsův parametrický test, který vyloučil maximální hodnotu $22468 \mathrm{~K} \check{c} / \mathrm{m}^{2}$, dalším zkoumáním byly vyloučeny i hodnoty které byly nižší než $45 \%$ ceny stanovené jako průměr z hodnot, tedy částky nižší než $3900 \mathrm{Kč} / \mathrm{m}^{2}$. Tyto částky dle průzkumu byly s největší pravděpodobností určeny spekulativně za účelem snižování povinných poplatků ze zákona. Tímto postupem se snížil počet prvků v databázi na 10 .

\subsection{Databáze vytvořená bez nevhodných prvků}

Pokud odstraníme prvky, které vykazují nějaké zásadní ovlivnění ceny opět se nám počet prvků výrazně redukuje. Velmi často nastávají situace, kdy zprvu z velké databáze nám pro výpočet tržní hodnoty zůstanou jeden nebo dva prvky. Takto malý počet již není dostatečný vzorek pro stanovení tržní hodnoty a je třeba vyhledat další. Pokud upravíme námi zvolenou databázi tak, aby nevykazovala zjevné nesrovnalosti, bude $\mathrm{v}$ databázi pouze 10 prvků (tab. 2).

Dle pravidel statistiky by se tržní hodnota pozemku s vysokou pravděpodobností měla pohybovat $\mathrm{v}$ rozmezí hodnot stanovených jako průměr \pm výběrová směrodatná odchylka. Průměr by měl být nejpravděpodobnější tržní hodnotou. Z naší databáze tedy vyplývá, 
Tab. 2 Databáze realizovaných prodejü bez zjevných nesrovnalostí.

Tab. 2 Database of the undertaken sales without obvious discrepancies.

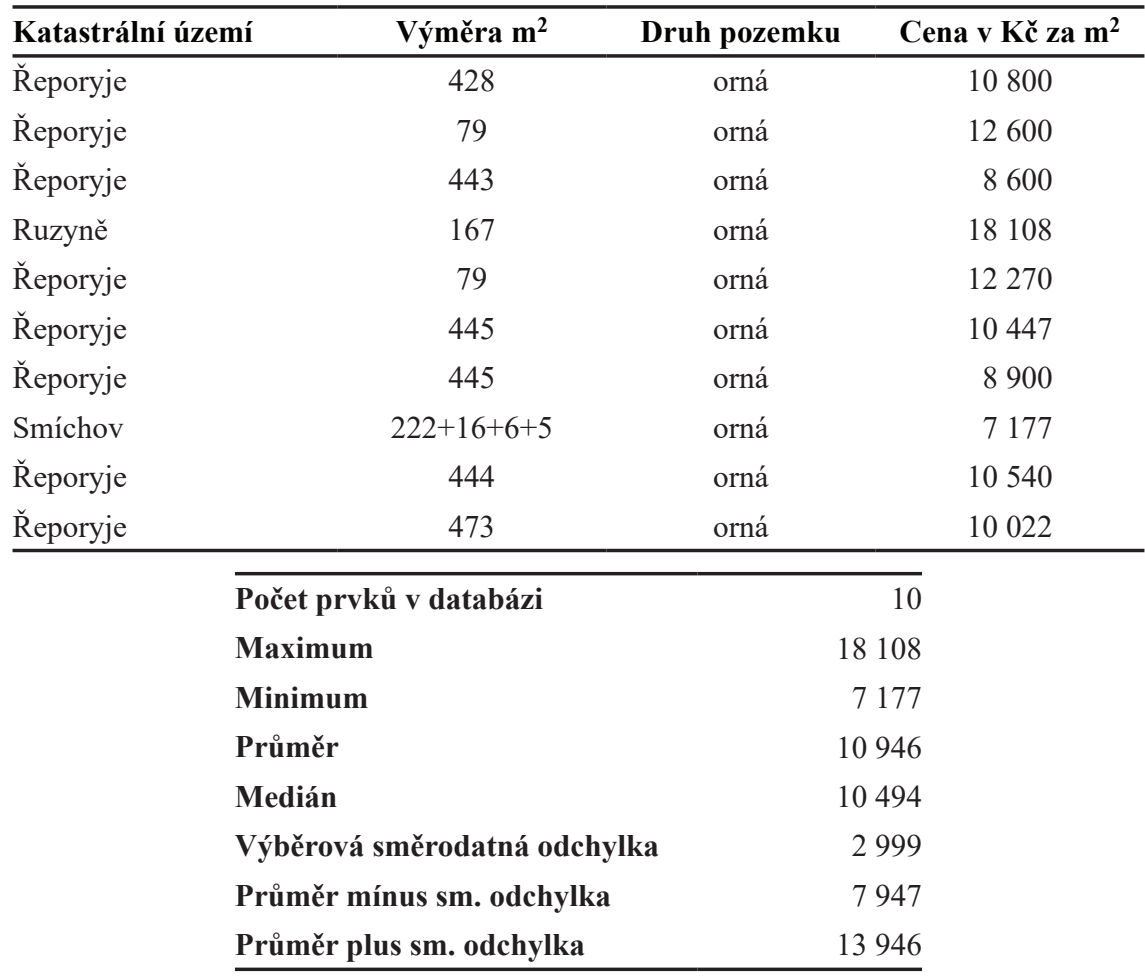

že tržní hodnota by se měla pohybovat v rozmezí $7947 \mathrm{Kč} / \mathrm{m}^{2}$ až $13946 \mathrm{Kč} / \mathrm{m}^{2}$. Nejpravděpodobnější tržní hodnotou by měla být částka $10946 \mathrm{Kč} / \mathrm{m}^{2}$. Rozptyl ve stanoveném rozmezí je stále velmi vysoký. Přri skutečném stanovení tržní hodnoty je tak tedy nutné dále podrobně zkoumat jednotlivé hodnoty v databázi a případné další nesrovnalosti, které nejsou hned zjevné eliminovat bud' vyřazením prvků $\mathrm{z}$ databáze nebo úpravou pomoc indexu odlišnosti.

\section{ZÁVĚR}

Závěrem lze konstatovat, že tvorba databáze pro výpočet tržní hodnoty pozemků není lehkým úkolem. Jak je zřejmé z našeho př́kladu i databáze o více jak 4000 prvcích nemusí být dostačující pro odhad tržní hodnoty jednoho pozemku. V našem př́kladu jsme vybrali pozemky se kterými se často obchoduje, a i přesto $z$ tak velké databáze jsme vybrali pouze 10 prvků, které by bylo třeba ještě dále upravovat. U pozemků jiného druhu jako jsou např́klad veřejná zeleň, pozemky pro výstavbu veřejně prospěšných staveb a podobně, se kterými se běžně neobchoduje, je tvorba databáze ještě výrazně složitější. Výběr vhodných pozemků je přitom zcela zásadní, pokud bychom vyjádřili odchylky v databázi číslem stanoveným jako průměrná hodnota, potom průměrná hodnota za $\mathrm{m}^{2}$ pozemku vypočtená z celé databáze o více jak 4000 prvcích bez provedeného výběru je $5335 \mathrm{Kč} / \mathrm{m}^{2}$, průměrná hodnota pozemku vypočtená $\mathrm{z}$ databáze vytvořené na základě základního výběru dle druhu pozemku v katastru nemovitostí a zařazení pozemku do stejných ploch v územním plánu je $9482 \mathrm{Kč} / \mathrm{m}^{2}$ a průměrná hodnota pozemků vypočtená $\mathrm{z}$ databáze dále upravené je $10946 \mathrm{~K} \check{c} / \mathrm{m}^{2}$. Hodnota vypočtená z celé databáze je pouze $49 \%$ a hodnota $\mathrm{z}$ databáze druhé je $87 \%$ z hodnoty vypočtené z poslední databáze. Správná volba porovnávaných pozemků tedy může ovlivnit cenu zásadním způsobem a u rozměrnějších pozemků může chybným výběrem docházet ke značným škodám.

\section{LITERATURA}

[1] BAREŠOVÁ, E., ŠANDOVÁ, H. Katastr nemovitostí, In: ASPI [právní informační systém], Wolters Kluwer ČR [cit. 4. 5. 2018]

[2] Zákon č. 151/1997 Sb., o oceňování majetku, ve znění pozdějších předpisů.

[3] ŠUSTROVÁ, D., BOROVIČKA, P., HOLÝ, J. Katastr nemovitostí. 2. vydání., Wolters Kluwer, Praha, 2017, 388 s. ISBN 978-80-7552-774-5.

[4] KLIKOVÁ, A., HAVLAN, P., CHADIMA, M., JURNÍKOVÁ, J., KADEČKA, S., PRŮCHA, P. SEDLÁČEK, S., SKULOVÁ, S., VENCLÍČEK, J. Správní ŕád. 2. vyd., Wolters Kluwer, Praha, 2016, 652 s. ISBN 978-80-7478-943-4.

[5] KLIKOVÁ, A., PRŮCHA, P. Veřejné stavební právo. 1. vydání, Masarykova univerzita, Brno, 2014, $157 \mathrm{~s}$. ISBN 978-80-210-7062-2.

[6] International Valuation Standards, International Valuation Standards Council, London, United Kingdom, 2017.

\section{Správná citace:}

KLIKA, P., KLIKOVÁ, A. Tvorba databáze pro oceňování pozemků. Soudní inženýrství, 2018, 29(4), 44-48.

DOI: http://dx.doi.org./10.13164/SI.2018.4.44. ISSN 1211-443X. 